\title{
Miscellany
}

\section{Tavistock Clinic advanced psychotherapy training}

For many years the Tavistock Clinic has provided a four year full-time multi-disciplinary Advanced Training in Adult Psychotherapy. In line with the main recommendation of the Government Review Group, that the Clinic be encouraged to develop as a national centre for psychotherapy training, the Clinic is now offering this training on a part-time basis to applicants working in Health Regions outside London.

Medical applicants will usually hold the post of Senior Registrar in Psychotherapy, Consultant Psychotherapist, or Consultant Psychiatrist with Special Responsibility for Psychotherapy, and will therefore be those who seek a full training in order to train others to a high standard where local resources are limited, or those who wish to strengthen their personal resources to meet the growing needs of teaching responsibilities. Course members will attend for two days a week (Thursdays and Fridays) for four years, and are required to have thrice weekly personal psychotherapy during this period. Clinical work will be done in the course member's own area.

Further details are available from Dr Denis Carpy, Consultant Psychotherapist, Tavistock Clinic, 120 Belsize Lane, London NW3 5BA (telephone 014357111 ).

\section{Dr Henry P. Laughlin}

Dr Laughlin, an Honorary Fellow of the College, served as Grand Marshal of the National Independence Day Parade on 4 July 1988 in Washington, DC in recognition of his work in all levels of the Sons of American Revolution, an organisation formed nearly a century ago to protect the institutions of government established by the country's founding fathers. Dr Laughlin donated the Laughlin Prize to the College (see page 504).

\section{Dr Alec Coppen}

Dr Alec Coppen, MRC Neuropsychiatry Research Laboratories, Epsom, has been elected President of the Collegium Internationale Neuro-Psychopharmacologicum (CINP).

\section{Dr Edmond Chiu}

Dr Edmond Chiu, Senior Lecturer in Psychiatry at Melbourne University, who is well known to many British psychiatrists for his special interests in psychogeriatrics and in Huntington's disease, has become a Member of the Order of Australia.

\section{New publication}

The National Development Team for People with a Mental Handicap have published a report, commissioned by South Warwickshire Health Authority, entitled 'A Question of Responsibility' which examines the complex and sometimes controversial issue of 'responsibility' within the context of new community care policies. Copies of this report are available from the Department of Health and Social Security, Room 113 Canons Park, Government Buildings, Honeypot Lane, Stanmore, Middlesex HA7 1AY, price $£ 1.20$. Cheques should be made payable to DHSS. The South Warwickshire Health Authority contact point for local enquiries is: $\mathrm{Mr}$ Frank Duffy, Westgate House, Market Street, Warwick CV34 4DE (telephone 0926 493491, extension 255).

\section{Psychiatrists against apartheid}

A newly formed group of College members is to look at issues relating to psychiatry and apartheid. For further details please contact Dr D. Hollander, Royal Northern Hospital, Holloway Road, London N7.

\section{Consent and the incompetent patient}

A conference convened by the Mental Health Act Commission and Cardiff Law School to discuss practical problems of consent in relation to mentally disordered patients who lack the capacity to consent to treatment, and possible solutions to these problems, will be held on 12 December 1988 at Cardiff Law School. For further details and booking forms contact: Consent Conference, Cardiff Law School, PO Box 427, The Law Building, Museum Avenue, Cardiff CF1 1XD (telephone 0222 874348) 